\title{
ANTI ARTHRITIC ACTIVITY OF TINOSPORA CORDIFOLIA LEAVES BY DENATURATION STUDIES
}

\author{
R.Ramya1, R.Maheswari2,* \\ ${ }^{1}$ Department of Biochemistry, K.M.G College of Arts \& Science, Gudiyattam, Vellore District, \\ Tamilnadu, India \\ ${ }^{2 *}$ Head, Department of Biochemistry, K.M.G College of Arts \& Science, Gudiyattam, Vellore \\ District, Tamilnadu, India. \\ Email: maheswarikmg2013@gmail.com
}

\begin{abstract}
The study was designed to evaluate the phytochemical screening and anti-arthritic activity of various bark extract of Tinospora cordifolia. The main objective of our study is to evaluate in vitro anti arthritic activity of various bark extracts of Tinospora cordifolia by using BSA denaturation method. Our study displayed that different bark extracts of Tinospora cordifolia (MLE, ELE and CFE) were able to inhibit the protein denaturation and can be used as an anti arthritic agent. The percentage of protein denaturation by different bark extracts of Tinospora cordifolia (MLE, ELE and CFE) were found to be 23\%, 36\%, 43\%

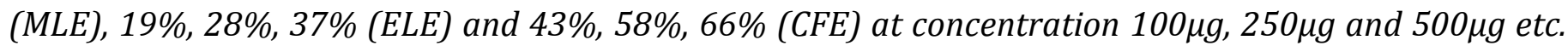
From the present studied it had been concluded that CFE, and MLE were exhibiting the potential capability to inhibit the denaturation of protein when compared with standard drug diclofenac sodium. The results indicate that the extract contains antioxidants and phytochemicals. Proximate analysis of Tinospora cordifolia showed wide variations but was in compliance to standard monographs. Qualitative analysis of Tinospora cordifolia extracts of stem part showed the presence of alkaloids, carbohydrates, glycosides, phytosterols, tannins, and saponin has found in watery extract.
\end{abstract}

Key words: Tinospora cordifolia, Bark, Methanol, Ethanol, Chloroform Extract, Antiarthritic, Diclofenac Sodium, BSA.

\section{INTRODUCTION}

Giloy (Tinospora cordifolia family Menispemaceae) is an indigenous, common shrub found in the Himalayas, tropical regions of India and particularly abundant in the dense forests of Chhattisgarh. Tinospora cordiofolia is a creeper with grayish stem and tubercles (small warts) on the surface. It is antipyretic, diuretic and anti-inflammatory. It constitute of several compound preparation. It is used in fever, urinary disorders, dyspepsia, secondary syphilis, rheumatism, constipation, tuberculosis, leprosy and general debility. It is also used in treatment of rheumatism and jaundice. It is a blood purifier and may be useful in AIDS and other immune disorders also. It is also being proposed for cancer patient before and after chemotherapy. The use of Tinospora cordifolia in the treatment of a variety of diseases in well documented. The present study included quantitative and qualitative evaluation of aerial part of Tinospora codiofolia. The quantitative evaluation parameter like moisture content, total ash value, acid insoluble ash, water soluble ash value, alcohol and aqueous extractive values were found to be $3 \%, 8 \%, 2 \%, 12 \%, 8 \%$ and $13 \%$ respectively. In qualitative evaluation, petroleum ether extract showed the presence of alkaloids, glycosides, carbohydrates, tannins, sterols, proteins and amino acids. The aqueous extract also showed 
the presence of alkaloids, glycosides, carbohydrates, tannins, proteins, and amino acids. Tinospora cordifolia growing with Neem (Azadirachta indica) is called as NEEM GILOY has chemical composition as similar as neem as well as giloy and show better therapeutic properties (Chaudhari S, 2013). The bark is creamy white to grey in colour and deeply left spirally (Khosa R.L, 1971). However, cortex of root is divided in to outer thick walled and inner parenchymatous zone (Aiyer K.N, 1963). Fruits develop during winter (Nadkarni K.M, 1976). The stem of this plant is generally used to cure diabetes by regulating level of blood glucose (Sangeetha M.K, 2011). The antidiabetic properties exhibited by this plant species are attributed due to the presence of alkaloids (Magnoflorine, Palmetine, Jatrorrhizine) (Patel M.B, 2011), tannins, cardiac glycosides, flavonoids, saponins, steroids etc., (Zinjarde S.S, 2011). T. cordifolia is well known for its immunomodulatory response. This property has been well documented by scientists (Tripathi YB, 1997; Bishayi B, 2002; Subramanian M, 2002).

\section{MATERIALS AND METHODS}

\section{CHEMICALS AND REAGENTS}

Tinospora cordifolia bark extract was procured as a gift from the Medical Shop, all other chemicals were purchased from Sigma-Aldrich, Chemicals Pvt. Ltd, India. All other chemicals used were of good quality and analytical grade.

\section{PREPARATION OF EXTRACT}

Weigh $20 \mathrm{~g}$ of Tinospora cordifolia stem powder paste into a $250 \mathrm{ml}$ round-bottomed flask. Add $50 \mathrm{ml}$ of methanol and $60 \mathrm{ml}$ of dichloromethane. Heat the mixture under reflux for $5 \mathrm{~min}$ on stem-bath with frequent shaking. Filter the mixture under suction and transfer the filtrate to a separatory funnel. Wash this mixture containing bioactive compounds with three portions of $150 \mathrm{ml}$ each with sodium chloride solution. Dry the organic layer over anhydrous magnesium sulfate. Filter and evaporate most of the solvent in vacuum without heating. Same procedure is followed for the extraction of MLE and CFE extracts.

\section{PRELIMINARY PHYTOCHEMICAL SCREENING}

Preliminary Phytochemical Screening has to be carried out for the identification of reducing sugars, pentoses, disaccharides, polysaccharides, proteins and amino acids phytosterols, polyphenols and carotenoids etc.

\section{METHOD}

Test solution $(0.5 \mathrm{ml})$ consists of $0.45 \mathrm{ml}$ of Bovine serum albumin $(5 \% \mathrm{w} / \mathrm{v}$ aqueous solution) and $0.05 \mathrm{ml}$ of test solution of various concentrations.

Test control solution $(0.5 \mathrm{ml})$ consist of $0.45 \mathrm{ml}$ of bovine serum albumin $(5 \% \mathrm{w} / \mathrm{v}$ aqueous solution) and $0.05 \mathrm{ml}$ of distilled water.

Product control $(0.5 \mathrm{ml})$ consists of $0.45 \mathrm{ml}$ of distilled water and $0.05 \mathrm{ml}$ of test solution.

Standard solution $(0.5 \mathrm{ml})$ consists of $0.45 \mathrm{ml}$ of Bovine serum albumin $(5 \% \mathrm{w} / \mathrm{v}$ aqueous solution) and $0.05 \mathrm{ml}$ of Diclofenac sodium of various concentrations.

Various concentrations $(100,250,500 \mu \mathrm{g} / \mathrm{ml})$ of test extracts and standard drug diclofenac sodium $(100,250,500 \mu \mathrm{g} / \mathrm{ml})$ were taken respectively. All the above solutions were adjusted to $\mathrm{pH} 6.3$ using $1 \mathrm{~N} \mathrm{HCl}$. The samples were incubated at $37^{\circ} \mathrm{C}$ for 20 minutes and the temperatures were increased to keep the samples at $57^{\circ} \mathrm{C}$ for 3 minutes. After cooling, add $2.5 \mathrm{ml}$ of phosphate buffer to the above solutions. The absorbance was measured using UV-Visible spectrophotometer at $416 \mathrm{~nm}$. The control represents $100 \%$ protein denaturation. The results were compared with Diclofenac sodium. All determinations were done in triplicate.

The percentage inhibition of protein denaturation can be calculated as: 
Percentage Inhibition

$=100$

(O.D of test solution - O. D of product control)

$\times 100$

\section{Pharmacognostical evaluation}

The stem part was subjected to proximate analysis. Quantitative standards like Moisture content, Total Ash value, Acid insoluble extractive values for aerial determined (Table 3, Table 4, Table 5).

\section{a) Moisture content}

The moisture content of a drug should be determined. Moisture content of the aerial part determined by using Infrared moisture balance Model - (Bell India Pvt. Ltd.) (Table 3).

\section{b) Ash value}

\section{1) Total ash value}

When vegetable drugs are incinerated, they leave an organic ash in some plants. The total ash usually contains carbonates, phosphate, silicate, and silica (Tabel 3)

\section{Calculation}

$$
\text { Ash } \%=(B-C) \times \frac{100}{A}
$$

Where, $\mathrm{A}$ is weight of sample in gram

$\mathrm{B}$ is weight of dish + content after drying ( $\mathrm{g}$ )

$\mathrm{C}$ is weight of empty dish (g)

\section{2) Acid insoluble ash}

Total ash treated with dilute hydrochloric acid reacts with minerals to form soluble salts and the insoluble ash consists mainly of silica, as acid insoluble ash (Table 3).

\section{c) Extractive values}

The determination of water and alcohol soluble extractive value was used as means of evaluating the quality and purity of the constituents. Extraction of the drug can be maceration with cold water or by continuous

extraction procession a Soxhlet extractor (Tale

3, Table 4).

\section{1) Alcohol soluble extractive values \\ 2) Water soluble extractive values Calculation}

The percentage of water soluble extractive values

Alcohol soluble extractive values

$$
=\frac{B-A \times 4 \times 100}{W}
$$

Where, $A=$ Empty weight of the dish (g)

$\mathrm{B}=$ Weight of dish + residue $(\mathrm{g})$

$\mathrm{W}=$ Weight of plant material taken $(\mathrm{g})$

\section{Preparation of extraction}

The stem part powder was subjected to systemic phytochemical screening by Extracting them with three solvents vizpetroleum ether and water. Then testing for the presence of chemical constituents.

\section{Solvent extraction}

The method is based on the extraction of active constituents present in the drug, using three solvents ranging from non-polar to polar. The solvents used petroleum ether \& water. The extraction was done using soxhlet apparatus.

\section{Procedure of Solvent Extraction}

\section{Extraction by soxhlet method}

$200 \mathrm{~g}$ of powdered bark extract was subjected drug was subjected to soxhlet extraction with two solvents, viz- petroleum ether and water for $6 \mathrm{hrs}$. All the extracts were concentrated by using rotary vacuum evaporator at low temperature. They were then weighed and percentage of different extractive values was calculated with respect to air-dried substance.

\section{DISCUSSIONS}




\section{PHYTOCHEMICAL SCREENING}

Preliminary Phytochemical screening of various extracts of papaya had shown the presence of various bioactive compounds such as carbohydrates (MLE, ELE and CFE), amino acids and peptides (MLE, ELE and CFE), phytosterols (CFE), carotenoids (MLE, ELE and CFE) and polyphenols (CFE) (Table 6).

\section{BIOLOGICAL SCREENING}

The in vitro anti arthritic results are using Bovine serum albumin denaturation method is given in Table 7 \& Graph 1, Denaturation of protein is an important cause of rheumatoid arthritis which is well documented. Production of auto antigen in certain arthritis may be due to the denaturation of protein. The inhibition of denaturation of protein may one of possible target for the treatment of arthritis. Our study displayed that different extracts of Tinospora cordifolia (MLE, ELE and CFE) were able to inhibit the protein denaturation and can be used as an anti arthritic agent. The percentage of protein denaturation by different extracts of Tinospora cordifolia (MLE, ELE and CFE) were found to be $23 \%, 36 \%, 43 \%$ (MLE), 19\%, 28\%, $37 \%$ (ELE) and 43\%, 58\%, 66\% (CFE) at concentration $100 \mu \mathrm{g}, 250 \mu \mathrm{g}$ and $500 \mu \mathrm{g}$ etc.

\section{PHRMACOGNOSTICAL EVALUATION}

The aerial part are subjected to quantitative standard (proximate analysis ) like moisture content, total Ash value, acid insoluble ash, extractive value and water soluble extractive values for sample were determined.

\section{a) Moisture Content}

Results of estimation of moisture content are tabulated in Table 3.

Analysis of the result is indicates that, in Tinospora cordifolia moisture content was maximum (3\%)

\section{b) Ash values}

The total ash, acid insoluble ash and watersoluble ash values were determined for air dried samples using the procedure described in anonymous, quality methods for medicinal plant materials, WHO, Geneva. From the results, both the plant parts shows slight difference were tabulated in Table 3.

Proximate analysis of Tinospora cordifolia showed wide variations but was in compliance to standard monographs. Qualitative analysis of Tinospora cordifolia extracts of stem part showed the presence of alkaloids, carbohydrates, glycosides, phytosterols, tannins, and saponin has found in watery extract.

\section{ACKNOWLEDGEMENT}

We are thankful to the faculty members of the PG \& Research Department of Biochemistry for their appreciativeness and making the necessary facilities available for the research. The authors would like to thank the Secretary \& Correspondent, Principal of K.M.G college Gudiyattam for their encouragement, providing the necessary facilities and support in carrying out the work.

\section{CONCLUSION}

The results obtained from the in-vitro studies performed by BSA denaturation method displayed that the various extracts of Tinospora cordifolia (MLE, ELE and CFE) possessed a very good anti arthritic activity. From the study it had been concluded that CFE, and MLE were exhibiting the potential capability to inhibit the denaturation of protein when compared with standard drug diclofenac sodium (Table 7 and Graph 1).

Proximate analysis of Tinospora cordifolia showed wide variations but was in compliance to standard monographs. Qualitative analysis of Tinospora cordifolia extracts of stem part showed the presence of alkaloids, carbohydrates, glycosides, phytosterols, tannins, and saponin has found in watery extract (Table 6). 
5. RESULTS

\begin{tabular}{|l|l|l|l|l|l|l|l|l|}
\hline $\begin{array}{l}\text { Sample } \\
\text { Identify }\end{array}$ & $\begin{array}{l}\text { Moisture } \\
\text { content } \\
\mathbf{\%}\end{array}$ & $\begin{array}{l}\text { Standard } \\
\text { Value }\end{array}$ & $\begin{array}{l}\text { Total } \\
\text { Ash } \\
\mathbf{\%}\end{array}$ & $\begin{array}{l}\text { Standard } \\
\text { Value }\end{array}$ & $\begin{array}{l}\text { Acid } \\
\text { Insoluble } \\
\text { Ash \% }\end{array}$ & $\begin{array}{l}\text { Standard } \\
\text { Value }\end{array}$ & $\begin{array}{l}\mathbf{H}_{2} \mathbf{0} \\
\text { Soluble } \\
\text { Ash \% }\end{array}$ & $\begin{array}{l}\text { Standard } \\
\text { Value }\end{array}$ \\
\hline $\begin{array}{l}\text { Tinospora } \\
\text { cordifolia }\end{array}$ & 3 & NMT 6\% & 8 & $\begin{array}{l}\text { NMT } \\
11 \%\end{array}$ & 2 & NMT 4\% & 13 & NMT 21\% \\
\hline
\end{tabular}

Table 3: Data showing values of moisture content, total ash acid insoluble ash, and Water soluble ash in Tinospora cordifolia.

\begin{tabular}{|l|l|l|l|l|}
\hline $\begin{array}{l}\text { Sample } \\
\text { Identify }\end{array}$ & $\begin{array}{l}\text { \% of Alcohol } \\
\text { Soluble Extractive }\end{array}$ & $\begin{array}{l}\text { Standard } \\
\text { Value }\end{array}$ & $\begin{array}{l}\text { \% of Water Soluble } \\
\text { Extractive }\end{array}$ & Standard Value \\
\hline $\begin{array}{l}\text { Tinospora } \\
\text { cordifolia }\end{array}$ & 8 & NMT 2\% & 13 & NMT 10\% \\
\hline
\end{tabular}

Table 4: Data showing \% Alcohol soluble extractive values and \% water soluble extractive values in Tinospora cordifolia stem part.

\begin{tabular}{|l|l|l|l|l|}
\hline $\begin{array}{l}\text { Plant } \\
\text { parts }\end{array}$ & Solvents & Colour & $\begin{array}{l}\text { Nature of the } \\
\text { extracts }\end{array}$ & Solubility \\
\hline $\begin{array}{l}\text { Stem } \\
\text { Part }\end{array}$ & Petroleum ether & Dark brown & Sticky & Chlorofrom, DMSO \\
\cline { 2 - 5 } & Water & Black brown & Sticky & Water, DMSO \\
\hline
\end{tabular}

Table 5: Data showing successive extractive values and nature of extracts of the

Tinospora cordifolia stem part.

\begin{tabular}{|c|c|c|c|}
\hline $\begin{array}{l}\text { Chemical } \\
\text { Constituent }\end{array}$ & Test's & $\begin{array}{l}\text { Petroleum } \\
\text { Ether }\end{array}$ & Aqueous \\
\hline \multirow[t]{4}{*}{ Alkaloids } & Mayers test & + & + \\
\hline & Dragendroff's test & + & + \\
\hline & Wagners test & + & + \\
\hline & Hagers test & + & + \\
\hline \multirow[t]{2}{*}{ Carbohydrates } & Mollisch's test & + & + \\
\hline & Benedicts test & + & + \\
\hline \multirow[t]{3}{*}{ Glycosides } & Modified Borntragers & + & + \\
\hline & Legal test & + & + \\
\hline & Killer killiani test & + & + \\
\hline \multirow[t]{2}{*}{ Saponins } & Foam test & - & + \\
\hline & Froth test & - & + \\
\hline \multirow[t]{2}{*}{ Phytosterols } & Salkowaski test & + & + \\
\hline & Libbermann burchard test & + & + \\
\hline Resins & Acetone water test & - & - \\
\hline Phenols & Ferric chloride test & - & - \\
\hline Tannins & Gelatin test & + & + \\
\hline Flavanoids & Alkaline reagent & - & - \\
\hline
\end{tabular}




\begin{tabular}{|l|l|l|l|}
\hline \hline \multirow{4}{*}{ Protiens } & Lead acetate test & - & - \\
\cline { 2 - 4 } & Shinoda test & - & - \\
\cline { 2 - 4 } & Ninhydrin test & - & - \\
\cline { 2 - 4 } & Xanyhoproteic test & - & - \\
\cline { 2 - 4 } & Biurete test & - & - \\
\hline
\end{tabular}

Table 6. Qualitative chemical tests of the extract of Tinospora cordifolia. [+Present, -Absent]

\begin{tabular}{|l|c|c|}
\hline Drug & Concentration $(\boldsymbol{\mu g} / \mathbf{m l})$ & \% Inhibition \\
\hline Test Control & - & - \\
\hline Product Control & - & - \\
\hline \multirow{3}{*}{ MLE Extract (Test) } & 100 & $23.5 \pm 3.5$ \\
\cline { 2 - 3 } & 250 & $36.6 \pm 4.3$ \\
\cline { 2 - 3 } & 500 & $43.6 \pm 3.2$ \\
\hline \multirow{3}{*}{ ELE Extract (Test) } & 100 & $19.7 \pm 2.5$ \\
\cline { 2 - 3 } & 250 & $28.6 \pm 2.6$ \\
\cline { 2 - 3 } & 500 & $37.4 \pm 3.3$ \\
\hline \multirow{3}{*}{ CFEE Extract (Test) } & 100 & $43.7 \pm 4.2$ \\
\cline { 2 - 3 } & 250 & $58.8 \pm 5.3$ \\
\cline { 2 - 3 } & 500 & $66.9 \pm 4.4$ \\
\hline \multirow{2}{*}{ Diclofenac Sodium } & 100 & $37.4 \pm 2.6$ \\
\cline { 2 - 3 } & 250 & $73.5 \pm 3.6$ \\
\cline { 2 - 3 } & 500 & $88.8 \pm 3.4$ \\
\hline
\end{tabular}

Table 7. Result of In-vitro anti-arthritic activity of drugs in BSA denaturation method Values are in Mean \pm SD, $n=3$.

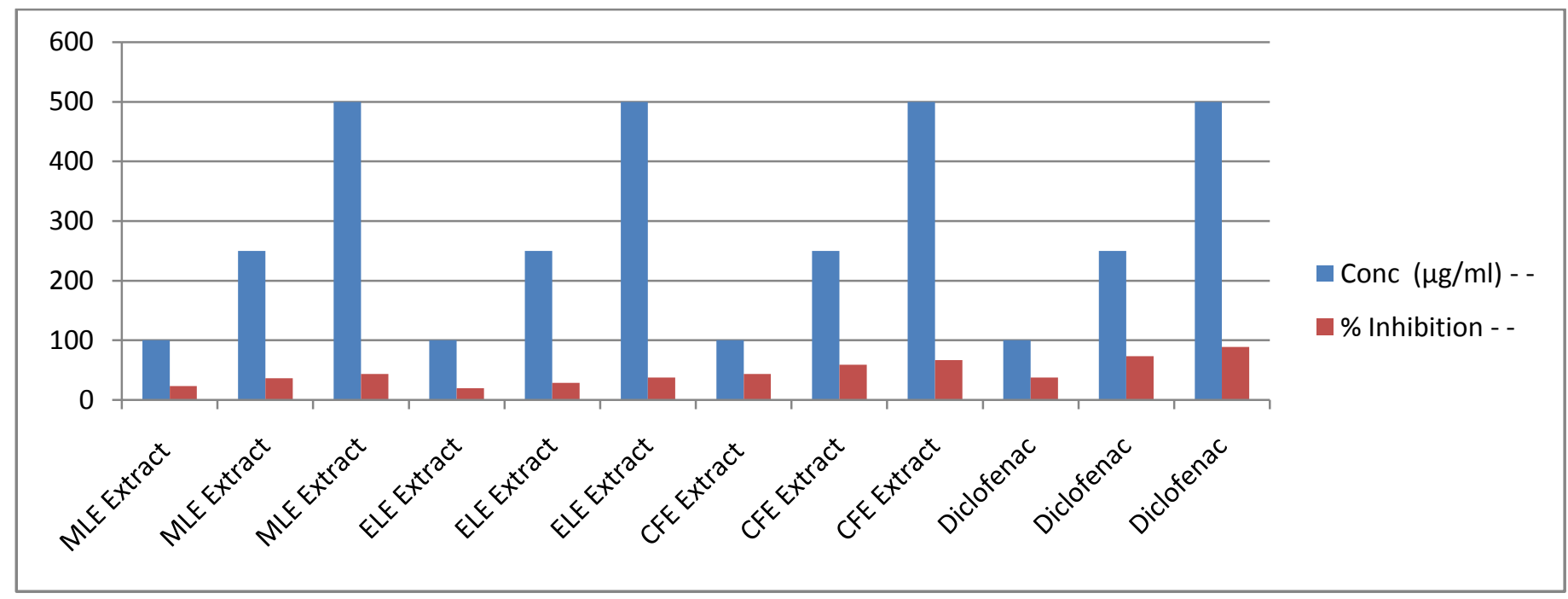

Graph 1. result of In-vitro anti-arthritic activity of drugs in BSA denaturation method.

\section{REFERENCES}

1. Papaw. Collins Dictionary. N D. Retrieved 25 September 2014.
2. http://canal.ugr.Es/lifesciences/item/6 354-scientists-decipher-fruit-tree genome-for-the-firsttime. 
3. Raj K Bansal. Laboratory manual of organic chemistry, $5^{\text {th }}$ revised edition, 2009; 238-239.

4. Dandiya P C, Sharma P K. Bio-chemistry and clinical pathology, second edition $2004 ; 17-18,24,47-48$.

5. G Devala Rao. A Manual of Practical Biochemistry 2006; 3 Rd Edition 17.

6. Jaswant Kaur, PV Chemistry of Natural Products, 2010 Edition, 113-114, 116, 344-346, 381.

7. Madan Singh, Prashant Soni, Neeraj Upmanyu and Yogesh Shivhare. In-vitro Anti-arthritic Activity of Manilkara zapota Linn. Asian J. Pharm. Tech. 2011; 1(4), 123-124.

8. Deshpande V, Jadhav VM and Kadam VJ. In-vitro antiarthritic activity of Abutilon indicum (Linn.) Sweet. Journal of Pharm. Res. 2009; 2(4): 644-645.

9. Seema Chaitanya Chippada and Meena Vangalapati. Antioxidant, an antiinflammatory and anti-arthritic activity of Centella asiatica extracts. J Chem Bio Phy Sci 2011, 1(2), Sec. B, 260- 269.

10. Sharan Suresh Volluri, Srinivasa Rao Bammidi, Seema Chaitanya Chippada and Meena Vangalapat. In-Vitro AntiArthritic Activity of Methanolic Extract of Bacopa Monniera International Journal of Chemical, Environmental and Pharmaceutical Research 2011; 2 (2) 156-159.

11. A Batra, S Mathur, GS Shekawat, J.Plant Biol., 2001, 28(3), 277-281.

12. HU XR, AF Yang, KW Zhang, J Wang, JR Zhang, Plant Cell Tissue org, Cult., 2006, 84 90-99.
13. AV Raghu, SP Geetha, G Martin, I Balachandran PN Ravindran, In vitro cell. Dev. Biol. -Plant, 2006, 42, 584-588.

14. Pratibha D Nadig1, Roshni R Revankar, Indian journal of pharmacology, 2012, 44(5), 580-583.

15. International Research Journal of Pharmaceutical and Applied Sciences, Available online at www.irjpas.com Int. Res J Pharm. App Sci., 2013; 3(5):210213.

16. Balandrin MF, Klocke JA, Wurtele ES, Bollinger WH. Natural Plant Chemicals: Sources of Industrial and Medicinal Materials. Science 1985; 228:11541160.

17. Briskin DP. Medicinal Plants and Phytomedicines, Linking Plant Biochemistry and Physiology to Human Health. American Society of Plant Physiology 2000; 124:507-514.

18. Daniel M. Medicinal Plants: Chemistry and Properties. vol.2, Science Publication, 2006, 2436.

19. Anonymous. Wealth of India: Raw materials. CSIR, New Delhi, 1976, 10.

20. Chaudhari S, Shaikh N. Gaduchi-the best ayurvedic herb. The Pharma Innovation Journal 2013; 2(4):97-102

21. National Medicine Plant Board. www.nmpb.nic.in. 04 April, 2014.

22. Khosa RL, Prasad S. Pharmacognostical studies on Guduchi (Tinospora cordifolia Miers). J Res Ind Med 1971; 6:261-269.

23. Aiyer KN, Kolammal M. Pharmacognosy of Ayurvedic Drugs. Edn 1, The Central Research Institute 1963, series 1. 
24. Raghunathan K, Sharma PV. The aqueous extract of $T$. cordifolia used reduction of blood sugar in alloxan induced hyperglycemic rats and rabbits. J Res Ind Med 1969; 3:203-209.

25. Kirtikar KR, Basu BD. Indian Medicinal Plants. Edn 2, Vol. 1, M/S Bishen Singh, Mahendra Pal Singh; 1975.

26. Nadkarni KM, Nadkarni AK. Indian Materia Medica. Edn 3, Vol. 1, M/S Popular Prakasan Pvt. Ltd 1976.

27. Upadhaya AK, Kumar K, Kumar A, Mishra HS. Tinospora cordifolia (Willd.) Hook. F. and Thoms. (Guduchi)-alidation of the Ayurvedic pharmacology through experimental and clinical studies. Int J Ayurveda Res 2010; 1:112-121.

28. Rout GR. Identification of Tinospora cordifolia (Willd.) Miers ex Hook F \& Thoms using RAPD markers. Z Naturforsch C 2006; 61:118-22.

29. Patel SS, Shah RS, Goyal RK. Antihyperglycemic, anti-hyperlipidemic and antioxidant effects of Dihar, a poly herbal ayurvedic formulation in streptozotocin induced diabetic rats. Indian J Exp Biology 2009; 47:564-570.

30. Gupta R, Sharma V. Ameliorative effects of Tinospora cordifolia root extract on histopathological and biochemical changes induced by aflatoxin-b (1) in mice kidney. Toxicol Int 2011; 18:94-98.

31. Jagetia GC, Rao SK. Evaluation of the antineoplastic activity of guduchi (Tinospora cordifolia) in ehrlich ascites carcinoma bearing mice. Biol Pharm Bull 2006; 29:460-466

32. Patel MB, Mishra S. Hypoglycemic activity of alkaloidal fraction of
Tinospora cordifolia. Phytomedicine 2011; 18:1045-1052.

33. Sriramaneni RN, Omar AZ, Ibrahim SM, Amirin S, Mohd ZA. Vasorelaxant effect of diterpenoid lactones from and rographis paniculata chloroform exract on rat aortic rings. Pharmacognosy Res 2010; 2:242-246.

34. Yang S, Evens AM, Prachands, Singh AT, Bhalla S, Devid $\mathrm{K}$ et al. Diterpenoid lactone and rographolide, the active component of andrographis paniculata. Clin Cancer Res 2010; 16:4755-4768.

35. Zhao F, He EQ, Wang L, Liu K. Antitumor activities of and rographolide, a diterpene from Andrographis paniculata, by inducing apoptosis and inhibiting VEGF level. J Asian Nat Prod Res 2008; 10:467-473.

36. Kohno H, Maeda M, Tanino M, Tsukio Y, Ueda $\mathrm{N}$, Wada $\mathrm{K}$ et al. A bitter diterpenoid furano lactone columbine from calumbae Radix inhibits azoxy methane-induced rat colon carcinogenesis. Cancer let 2002; 183:131-139.

37. Dhanasekaran M, Baskar AA, Ignacimuthu $\mathrm{S}$, Agastian $\mathrm{P}$, Duraipandiyan V. Chemopreventive potential of Epoxy clerodane diterpene from Tinospora cordifolia against diethyl nitrosamine induced hepyocellular carcinoma. Invest New Drugs 2009; 27:347-355

38. Ly PT, Singh S, Shaw CA. Novel environmental toxins: Steryl glycosides as a potential etiological factor for agerelated neurodegenerative diseases. J Nrurosci Res 2007; 85:231-237. 
39. Karpova EA, Voznyi YV, Dudukina TV, Tsvetkva IV. $4-$ Trifluoromethylumbelliferyl glycosides as new substrates form revealing diseases connected with hereditary deficiency of lysosome glycosidases. Biochem Int. 1991; 24:1135-1144.

40. Kapil A and Sharma S. Immunopotentiating compounds from Tinospora cordifolia. J Ethopharmacol 1997; 58:89-95.

41. Chen S, Wu K, Knox R. Structurefunction studies of DT-diaphorase (NQ01) and NRH: Quinone oxidoreductase (NQO2). Free Radic Biol Med. 2001; 29: 276-284.

42. Badwin AS. Control of oncogenesis and cancer therapy resistance by the transcription factor NF-kappa B. J of Clin Invest 2001; 107:241-246.

43. Yang JH, Kondratyuk TP, Marler LE, Qiu $\mathrm{X}$, Choi $\mathrm{Y}$, Caoh et al. Isolation and evaluation of kaempferol glycosides from the fern neo-cheiropterispalmatope data. Phytochemistry 2010; 71:641-647.

44. Kim SK, Kim HJ, Choi SE, Park KH, Choi HK, Lee MW. Antioxidative and inhibitory activities on nitric oxide (NO) and prostaglandin E2 (COX-2) production of flavonoids from seeds of prunustomentosa Thunberg. Arch Pharm Res 2008; 31:424- 428

45. Lv J, Xu D, Perkovic V, Ma X, Johnson DW, Woodward M et al. Corticosteroid therapy in IgA nephropathy. J Am Soc Nephrol 2012; 23:1108-16.

46. McKeown E, Bykerk VP, Deleon F, Bnner A, Thorne C, Hitchon CA et al. Quality assurance study of the use of preventative

therapies

in

glucocorticoid-induced osteoporosis in early inflammatory arthritis: Result from the CATCH cohort. Rheumatology (Oxford) 2012; 51:1662-1669.

47. Sundarraj S, Thangam R, Sreevani V, Kaveri K, Gunasekaran P, Achiraman S et al. $\Upsilon$-Sitosterol from acacia nilotica $\mathrm{L}$. induces G2/M cell cycle arrest and apopyosis through c-Myc suppression in MCF-7 and A549 cells. J Ethnopharmcol 2012; 141:803-809.

48. Maurya R, Handa SS. Tinocordifolin, a sesquiterpene from Tinospora cordifolia. Phytochem 1998; 49:1343-1346.

49. De-Oliveria AM, Conserva LM, De-Souza Ferro JN, De-Almeida Brito F, Lyra Lemos RP, Barreto E. Antinociceptive and anti-inflammatory effects of octacosanol from the leaves of sabiceagrisea var. Grisea in mice. Int J Mol Sci 2012; 13:1598-1611.

50. Wang T, Liu YY, Wang X, Yang N, Zhu HB, Zuo PP. Protective effects of octacosanol on 6-hydroxydopamineinduced Parkinsonism in rats via regulation of ProNGP and NGF signalling. Acta Pharmacol Sin 2010; 31:765-774.

51. Thippeswamy G, Sheela ML, Salimath BP. Octacosanol isolated from Tinospora cordifolia downregulates VEGF gene expression by inhibiting nucular translocation of $\mathrm{NF}<\mathrm{kappa}>\mathrm{B}$ and its DNA binding activity. Eur J Pharmcol 2008; 588:141-150.

52. Ghosh AK, Chapsal BD, Webar IT, Mitsuya H. Design of HIV protease inhibitors targeting protein backbone: An effective strategy for combating drug 
resistance. Acc Chem Res 2008; 41:7886.

53. Mukherjee R, De-UK, Ram GC. Evaluation of mammary gland immunity and therapeutic potential of Tinospora cordifolia against bovine subclinical mastitis. Trop Anim Health Prod 2010; 42:645-651

54. Sangeetha MK, Balaji HR, Gayathri V, Vasanthi HR. Tinospora cordifolia attenuates oxidative stress and distorted carbohydrate metabolism in experimentally induced type 2 diabetes in rats. J Nat Med 2011; 65:544-550.

55. Zinjarde SS, Bhargava SY, Kumar AR. Potent $\alpha$-amylase inhibitory activity of Indian Ayurvedic medicinal plants. BMC Complement Altern Med 2011; 11:1.

56. Chougale AD, Ghadyale VA, Panaskar SN, Arvindekar AU. Alpha glycosidase inhibition by stem extract of Tinospora cordifolia. J Enzyme Inhib Med Chem 2009; 24:998-1001.

57. Umamaheswari S, Mainzen PPS. Antihyperglycaemic effects of 'IlogenExcel' an ayurvedic herbal formulation in streptozotocin induced diabetes mellitus. Acta pol Pharma 2007; 64:5361.

58. Tripathi YB, Sharma M, Manickam. Rubia 5 din, a new antioxidant from rubia cordifolia. Ind J Biochem Biophy 1997; 34:302-306.

59. Bishayi B, Roychowdhury S, Ghosh S, Sengupta M. Hepatoprotective properties of a

60. Tinospora cordifolia in CCl4 intoxicated mature albino rats. J Toxic Sci 2002; 27:139-146.
61. Subramanian M, Chintawar GJ, Chattopadhyay S. Antioxidant properties of Tinospora cordifolia polysaccharide against iron-mediated lipid damage and gamma-ray induced protein damage. Redox Rep 2002; 7:137-143

62. Sharma P, Parmar J, Sharma P, Verma P, Goyal PK. Radiation- induced testicular injury and its amelioration by $T$. cordifolia (An Indian Medicinal plant) extract. Evid based comp altern Med 2012; 643-647.

63. Upadhyay PR, Sharma V, Anita KV. Assessment of the multi faceted immunomodulatory potential of the aqueous extract of Tinospora cordifolia. Res J Chem Sci 2011; 1:71-79.

64. More $\mathrm{P}$, Pai K. In vitro NADH-oxidase and myeloperoxidase activity of macrophages after Tinospora cordifolia (guduchi) treatment. Immuno Pharma Immuno toxic. 2010; 34:368-372.

65. Sharma V, Pandey D. Protective role of Tinospora cordifolia against lead induced hepatotoxicity. Toxic Int 2010; 17:12-17

66. Sharma V, Pandey D. Beneficial effects of Tinospora cordifolia on blood profiles in male mice exposed to lead Toxic Int 2010; 17:12-17.

67. Kalikae MV, Thawani VR, Varadpande UK, Santakke SD, Singh RP, Khiyani RK,. Immunomodulatory effect of $T$. cordifolia extract in HIV positive patients. Ind J pharmacol 2008; 40:107110.

68. Akhtar S. Use of T. cordifoliain HIV infection. Ind J pharmacol. 2010; 42:5763 
69. Diwanay S, Chitre D, Patwardhan B. Immunoprotection by botanical drug on experimental metastasis. J ethano pharmacol 2004; 90:223-237.

70. Jagetia GC, Nayak V, Vidyasagar MS. Evaluation of the antineoplastic activity of guduchi (Tinospora cordifolia) in cultured HeLa cells. Cancer let 1998; 127:71-82.

71. Narayanan AS, Raja SS, Ponmurugan K, Kandekar SC, Maripandi A. Antibacterial activity of selected medicinal plant against multiple antibiotic resistant uropathogens: A study from Kolli Hills, Tamilnadu, India. Benef Microbes 2011; 2:235-243.

72. Jayachandran R, Xavier TF, Anand SP. Antibacterial activity of stem extracts of Tinospora cordifolia (willd.) Hook. F. and Thoms. Anc Sci Life 2003; 22:40-43

73. Ambekar DH, Khante BS, Chandak BR, Titare AS, Baralkar SS, Aghadte SN. Screening of antibacterial potential of some medicinal plants from Melghat forest in India. Afr J Trad Comp Altern Med 2009; 6:228-232.

74. Sengupta S, Mukherjee A, Goswami R, Basu S. Hypoglycemic activity of the antioxidant saponarin, characterized as alpha-glucosidase inhibitor present in Tinospora cordifolia. J Enzyme Inhib Med Chem 2009; 24:684-690.

75. Stanely P, Menon VP. Hypoglycaemic and hypolipidemic action of alcohol extract of Tinospora cordifolia roots in chemical induced diabetes in rats. Phytother Res 2003; 17:410-413.

76. Stanely P, Menon VP. Antioxidant action of Tinospora cordifolia root extract in alloxan diabetic rats", Phytother Res 2001; 15:213-218.

77. Rawal A, Muddeshwar M, Biswas S. Effects of $R$. cordifolia, $F$. creticalinn., $T$. cordifolia on free radical generation and lipid peroxidation during oxygen glucose deprivation in rat hippocampal slices. Biochem Biophy Res Com 2004; 324:588-596.

78. Kapur P, Wuttke W, Jarry H. Beneficial effects of beta-ecdysone on the joint epiphyseal cartilage tissue and trabecular bone in ovariectomized rats. Phytomedecine 2010; 17:350-355.

79. Sarma DNK, Koul S, Khosa RL. Alkaloids from Tinospora cordifolia Miers. J Pharm Sci \& Res 2009; 1(1):26-27

80. Rao BR, Kumar DV, Amrutha RN, Jalaja $\mathrm{N}$, Vaidyanath K, Rao AM et al. Effect of growth regulators, carbon source and cell aggregate size on berberine production from cell cultures of Tinospora cordifolia Miers. Curn Trends Biotech and Pharma 2008; 2 (2):269276

81. Gururaj HB, Giridhar P, Ravishankar GA. Micropropagation of Tinospora cordifolia (Willd.) Miers ex Hook. F and Thoms- a multipurpose medicinal plant. Cur Sci 2007; 92(1):23-26.

82. Khanapurkar RS, Paul NS, Desai DM, Raut MR, Gangawane AK. In-Vitro Propagation OF Tinospora cordifolia (Wild.) Miers ex Hook. F. Thoms. J Bot Res 2012; 3(1):17- 20.

83. Raghu AV, Geetha SP, Martin G, Balachandran I, Ravindran PN. In vitro Clonal Propagation through Mature Nodes of Tinospora cordifolia (WILLD.) HOOK. F. and THOMS: An Important 
Ayurvedic Medicinal Plant. In vitro Cell

Dev Bio Plant 2006; 42:584-588.

84. Rana V, Thakur K, Sood R, Sharma V, Sharma TR. Genetic diversity analysis of Tinospora cordifolia germplasm collected from north-western Himalayan region of India. J Genet 2012; 91:99-103.

85. Ishnava K, Mohan JSS. Assessment of genetic diversity in medicinal climber of Tinospora cordifolia (willd.) Miers (Menispermaceae) from Gujrat, India. Asian Journal of biotech 2009; 14:114118.

86. Ahmed SM, Verma V, Qazi PH, Ganaie MM, Bakshi SK, Qazi GN. Molecular phylogeny in Indian Tinospora species by DNA based molecular markers. Plant Syst E 2006; 256:75-87

87. Rajathi K, Vijayaraj D, Anarkali J, Sridhar S. Green Synthesis, Characterization and In- Vitro Antibacterial Activity of Silver Nanoparticles By Using Tinospora Cordifolia Leaf Extract. Int J Green Chem and Biop 2012; 2(2):15-19.

88. Desai VR, Kamat JP, Sainis KB. An immunomodulator from Tinospora cordifolia with antioxidant activity in cell free systems. Proc Ind Acad Sci (Chem Sci) 2002; 114(6):713-719.

89. Singh S, Srivastava R, Choudhary S. Antifungal and HPLC analysis of the crude extracts of Acorus calamus, Tinospora cordifolia and Celastrus paniculatus. J Agri Tech 2010; 6(1):149158.

90. Singh N, Kumar A, Gupta P, Chand K, Samant M, Maurya R et al. Evaluation of antileishmanial potential of Tinospora sinensis against experimental visceral leishmaniasis. Parasitol Res 2007; 102:561-565.

91. Sharma A, Gupta A, Singh S, Batra A. Tinospora cordifolia (Willd.) Hook. F. and Thomson - A plant with immense economic potential. J Chem Pharm Res 2010; 2(5):327-333

92. Sinha K, Mishra NP, Singh J, Khanuja SPS. Tinospora cordifolia, Guduchi, a reservoir plant for therapeutic application: A review. Ind. J of Trad Know 2004; 3(3):257-270.

93. Singh SS, Pandey SC, Srivastava S, Gupta VS, Patro B, Ghosh AC. Chemistry and medicinal properties of Tinospora cordifolia (guduchi). Ind J Pharma 2003; 35:83-91.

94. Shah S, Ghosh S. Tinospora cordifolia: One plant many role. Ancs Life of sci 2012; 31:151-159.

95. Sharma S, Rathi N, Kamal B, Pundir D, Kaur B, Arya S. Conservation of biodiversity of highly important medicinal plants of India through tissue culture technology- a review. Agri and Bio J North America 2010; 1(5):827833.

96. Rout GR. Identification of Tinospora cordifolia (Willd.) Miers ex Hook F. \& Thomas Using RAPD Markers. Z. Naturforsch 2006; 61:118-122.

97. Rose MF, Noorulla KM, Asma M, Kalaichelvi R, Vadivel K, Thangabalan B, and Sinha BN. In vitro antibacterial activity of methanolic root extract of Tinospora cordifolia (willd). IJPRD 2007; 2(5):1-5.

98. Devprakash, Srinivasan KK, Subburaju T, Gurav1 S, Singh S. Tinospora cordifolia: A Review On Its Ethno 
botany, Phytochemical \& Pharmacological Profile. Asian J Biochem and Pharma Res 2011; 1(4):291-302.

99. Maridass M, De-Britto AJ. Origins of Plant Derived Medicines. Ethno botanical Leaflets 2008; 12:373-387.

100. Sonaimuthu V, Krishnamoorthy S, Johnpaul M. Taxol producing endophytic fungus Fusarium culmorum SVJM072 from medicinal plant of Tinospora cordifolia - a first Report. J of Biotech 2010; 09:425.

\section{Patel MB, Mishra SM.} Magnoflorine from Tinospora cordifolia stem inhibits aglucosidase and is antiglycemic in rats. J of Functional Foods 2012; 4:79-86. 86.

102. Sangeethaa MK, Priya CDM, Vasanthia HR. Anti-diabetic property of Tinospora cordifolia and its active compound is mediated through the expression of Glut-4 in L6 myotubes. Phytomedicine 2013; 20:246-248.

103. Kapura P, Pereiraa BMJ, Wuttke W, Jarry H. Androgenic action of Tinospora cordifolia ethanolic extract in prostate cancer cellline LNCaP. Phytomedicine 2009; 16:679-682.

104. Mallick S, Prakash BS. Effects of supplementation of Tinospora cordifolia to crossbred cows peripartum. Animal Reproduction Science 2011; 123:5-13

105. Jayaganthan $P, \quad$ Perumal P, Balamurugan TC, Verma RP, Singh LP, Pattanaik AK et al. Effects of Tinospora cordifolia supplementation on semen quality and hormonal profile in rams. Animal Repro Sci 2013; 140:47-53.
106. Nagarkar B, Kulkarni R, Bhondave P, Kasote D, Kulkarni O, Harsulkar A et al. Comparative Hepatoprotective Potential of Tinospora cordifolia, Tinospora sinensis and Neemguduchi. British J of Pharma Res 2013; 3(4):906-916.

107. The anti-mycobacterial activity of Tinospora Cordifolia medicinal plant used for the treatment of leprosy and Tuberculosis. Int J of Sci \& Eng Res 2013; 4(6):2953-2932.

108. Jayaseelan C, Rahuman AA, Rajakumar G, Kirthi KV, Santhoshkumar $\mathrm{T}$, Marimuthu $\mathrm{S}$ et al. Synthesis of pediculocidal and larvicidal silver nanoparticles by leaf extract from heart leaf moonseed plant, Tinospora cordifolia Miers. Parasitol Res 2011; 109:185-194.

109. Tan RX, Zou WX. Endophytes: a rich source of functional metabolites. Nat Prod Rep 2001; 18:448-459.

110. Strobel G, Daisy B. Bioprospecting for Microbial Endophytes and Their Natural Products. Microbio Mol Biol Rev 2003; 67:4491502.

111. Gaiero JR, Mc-Call CA, Thompson KA, Day NJ, Best AS, Dunfield KE. Inside the root micro biome: Bacterial root endophytes and plant growth promotion. Am J Bot 2013; 100(9):1738-1750.

112. Singh A, Sharma MM, Batra A. Synthesis of gold nanoparticles using Chick pea leaf extract using green chemistry. J of Optoelectronics and Biomed Maters 2013; 5(2):27-32. 
113. Singh A, Jain D, Upadhyay MK, Khandelwal N, Verma HN. Green Synthesis of Silver Nanoparticles using Argemone mexicana Leaf Extract and Evaluation of their Antimicrobial Activities. Dig J of Nanomater and Biostr 2010; 5(2):483-489.

114. Thirumurugan $\mathrm{T}$, Kaur K. Biological Synthesis and Characterization of Gold Nanoparticles from Pomegranate. Int $\mathrm{J}$ of Future Biotech 2013; 2(2):1-11.

115. Asghari G, Varshosaz J, Shahbazi N. Synthesis of silver nanoparticle using Portulaca oleracea L. extracts. Nanomedicine journal 2014; 1(2):94-99.

116. Pasca RD, Mocanu A, Cobzac SC, Petean I, Horovitz O, Cotisel MT. Biogenic Syntheses of Gold Nanoparticles Using Plant Extracts. Partic Sci and Tech An Int J 2014; 32(2):131-137.

117. Joladarash D, Chilkunda ND, Salimath PV. Glucose uptakestimulatory activity of Tinospora cordifolia stem extracts in Ehrlich ascites tumor cell model system. J Food Sci Technol 2014; 51(1):178-182. 